\section{Ks. Artur Malina}

Uniwersytet Śląski, Katowice

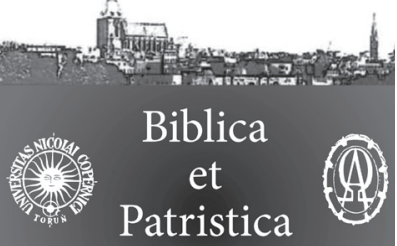

Thoruniensia

7 (2014) 4 ISSN 1689-5150

\title{
Dlaczego uczniowie nie mogli opowiadać o przemienieniu Jezusa? Studium Mk 9,9 w kontekście
}

\section{Why Should the Disciples Not Tell about the Transfiguration? Study of Mk 9:9 in the Context}

Słowa klucze: Ewangelia Marka; analiza narracyjna; przemienienie Jezusa; Mk 9,2-13.

Keywords: Gospel of Mark; narrative analysis; transfiguration of Jesus; Mark 9:9.

Streszczenie. Podczas zejścia z góry przemienienia Jezus nakazał trzem uczniom, aby nikomu nie opowiadali o tym, co widzieli, zanim Syn Człowieczy nie powstanie z martwych (Mk 9,9). Powodu tego polecenia zachowania milczenia oraz znaczenia jego ograniczenia czasowego nie można zrozumieć bez uwzględnienia bezpośredniego kontekstu: całego opowiadania o przemienieniu od wstąpienia Jezusa z trzema uczniami na górę aż do ich zejścia z niej. Narracja ta odsłania potrzebę uczniów, by słuchali nieustannie Jezusa oraz zachowali wolność od wpływów innych nauczycieli.

Abstract. Jesus ordered the three disciples to tell no one what they had seen, until the Son of Man had risen from the dead, when they came down from the mountain of the transfiguration (Mk 9:9). The reason of this command to silence and the meaning of this time limit cannot be understood without its immediate context: the whole account of the transfiguration from Jesus' ascent of the mountain with the tree disciples to their descent from it. This story shows the need of the disciples to heed constantly Jesus' words and to remain free from influence of other teachers.

Zukającym odpowiedzi na tytułowe pytanie nie pomaga ani podział tekstu Ona perykopy w najbardziej rozpowszechnionym przekładzie na język polski, ani ich wyodrębnienie w lekcjonarzach. Rozdzielają one scenę zejścia z góry przemienienia między dwie perykopy: opowiadanie o przemienieniu zawiera skierowany do uczniów Jezusa nakaz milczenia i ich dyskusję nad znaczeniem 
wzmianki o zmartwychwstaniu; osobną jednostkę tworzy ich pytanie o doktrynę uczonych w Piśmie odnośnie do przyjścia Eliasza oraz odpowiedź Jezusa ${ }^{1}$.

\section{Jedność narracji}

Analiza perykop nie powinna zależeć od podziałów ustalonych w najnowszych wydaniach czy w księgach liturgicznych ani nawet nie może opierać się na dawnych oznaczeniach w manuskryptach ${ }^{2}$. Początek i koniec narracji wyróżniają natomiast łatwo identyfikowane przez czytelnika zmiany czasu, miejsca, osób i akcji ${ }^{3}$. Elementy te nie tylko oznaczają granice większych i mniejszych jednostek literackich, lecz także stanowią o ich jedności narracyjnej, dynamice opowiadań i ich relacjach $\mathrm{z}$ najbliższym kontekstem. Tak zdeterminowane granice i miejsce perykop w strukturze księgi wyrażają intencję ewangelistów.

1 W Biblii Tysiąclecia rozmowa Jezusa z uczniami podczas schodzenia z góry przemienienia, która jest przedstawiona jako osobna perykopa (Mt 17,11-13; Mk 9,11-13), nosi tytuł: „Przyjście Eliasza”. Ten sam podział ma Synopsis Quattuor Evangeliorum. Locis parallelis evangeliorum apocryphorum et patrum adhibitis, ed. K. Aland, Deutsche Bibelstiftung, Stuttgart $1976^{9}$. Natomiast najnowsze wydanie krytyczne Nowego Testamentu łączy teksty o przemienieniu i zejściu z góry w jedną perykopę zatytułowaną "The Transfiguration of Jesus” (The Greek New Testament, ed. K. Aland, M. Black, C.M. Martini, B.M. Metzger, A. Wikgren, Deutsche Bibelgesellschaft - American Bible Society - United Bible Societies, New York $2014^{5}$ ).W interpretacji nie pomaga również wyodrębnienie fragmentów przeznaczonych do czytań liturgicznych: na Drugą Niedzielę Wielkiego Postu w Roku Liturgicznym B jest przewidziane czytanie Mk 9,2-10 bez zakończenia zawierającego pytanie uczniów w sprawie przyjścia Eliasza $(9,11)$ oraz odpowiedź Jezusa $(9,12-13)$. Przykładem zależności od przyjętych podziałów jest obszerna monografia poświęcona ewangelicznym narracjom o przemienieniu: J.P. Heil, The Transfiguration of Jesus. Także polskie komentarze do Ewangelii Marka analizują narrację o zejściu z góry przemienienia jako odrębną perykopę: H. Langkammer, Ewangelia według św. Marka, s. 220-222.

2 Na przykład w Kodeksie Watykańskim (B), w którym nie tylko poszczególne wyrazy, ale także zdania i grupy zdań są zapisywane bez przerw (scriptio continua), wolne miejsca między literami występują przed wyrażeniem, które otwiera opowiadanie o prze-

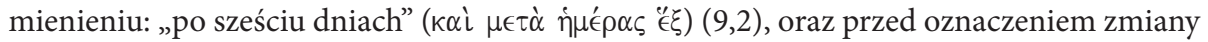

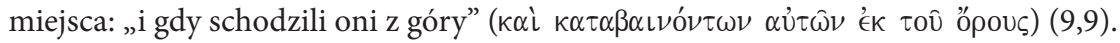

3 Por. W. Egger, Metodologia del Nuovo Testamento, s. 55. Kryteria delimitacji w tekstach narracyjnych (zmiany miejsca, czasu, osób i akcji, które oznaczają początek i koniec opowiadanych scen) mają swoje odpowiedniki w mowach: zmiana adresata wypowiedzi, zmiana jej gatunku (np. przejście z przypowieści do jej wyjaśnienia lub do cytatu biblijnego itp.), zmiana tematu, obecność stałych formuł. 


\subsection{Oznaczenie chronologiczne}

Wyraźna informacja o zmianie czasu jest najbardziej znaczącą cechą początku nowej narracji. Wzmianka o liczbie sześciu dni oznaczających upływ czasu jest dokładniejsza od wyrażenia występującego na początku opowiadania o odpuszczeniu grzechów paralitykowi: „po kilku dniach” ( $\delta \iota^{\prime} \dot{\eta} \mu \epsilon \rho \hat{\omega} \nu \mathrm{w} 2,1$ ). Podobna nieokreśloność charakteryzuje oznaczenie chronologiczne „w tamtych

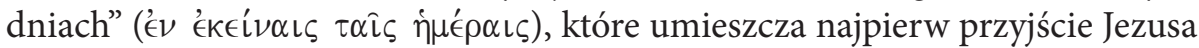
nad Jordan i przyjęcie przez Niego chrztu od Jana $(1,9)$ w szeroko ujmowanym okresie działalności Chrzciciela (1,4-8), a następnie rozmnożenie chlebów dla czterech tysięcy $(8,1)$ podczas drogi Jezusa z okolic Tyru i Sydonu do granic Galilei $(7,31)^{4}$. Ogólne są także oznaczenia początku i końca dnia $(1,32.35$; $4,35 ; 6,47)$. W pierwszej połowie Ewangelii jej autor podaje wprawdzie informacje o liczbie dni określającej upływ czasu, ale odnoszą się one do trwania poszczególnych wydarzeń: czterdzieści dni Jezus przebywa na pustyni kuszony przez diabła $(1,13)$; przez trzy dni, nie troszcząc się o pożywienie, tłum słucha Go w miejscu pustynnym $(8,2)$. Natomiast w jej drugiej połowie ewangelista odnosi się do daty wydarzeń liczonych względem Paschy: na dwa dni przed tym świętem przeciwnicy zastanawiają się nad Jego zabiciem $(14,1)$, natomiast pierwszego dnia Przaśników uczniowie pytają Go o miejsce spożywania wieczerzy paschalnej $(14,13)$.

Informacja o upływie sześciu dni różni się od powyższych określeń chronologicznych, ponieważ nie tylko wyodrębnia przedstawioną scenę od sąsiednich epizodów, lecz także w podanym czasie nie umieszcza żadnego wydarzenia. Do tego miejsca działalność Jezusa jest przedstawiana prawie nieprzerwanie. Jedynie w czasie misji Dwunastu Apostołów (6,12-13.31) Ewangelista nie referuje żadnego czynu ani słowa Jezusa, ponieważ opowiada o śmierci Jana Chrzciciela (6,14-29). Informacja o sześciu dniach przywołuje odniesienia do liczby dni w trzech zapowiedziach męki, śmierci i zmartwychwstania Syna Człowieczego. Ich wspólnym elementem jest zwrot: „Syn Człowieczy [...] po trzech dniach zmartwychwstanie" $(8,31 ; 9,31 ; 10,34)^{5}$; oznacza on czas, który poprzedza bezpośrednio zmartwychwstanie, gdy działania ludzi, dążących do wyeliminowania Syna Człowieczego, wydają się kończyć sukcesem. W tym czasie Jezus oczywiście więcej nie działa, a na zakończenie tego czasu decydujące okazuje się działanie Boga. Innymi słowy, okres oznaczony przez liczbę dni nie jest czasem Bożej nieobecności, lecz z jednej strony jest wyznaczony przez Niego i zgodny z Jego wolą, a z drugiej - całkowicie niezależny od inicjatywy ludzi

4 W 13,24 oznacza natomiast dni ostatecznego przyjścia Syna Człowieczego.

5 W sensie metaforycznym jako zapowiedź zburzenia przybytku w 14,58; 15,29. 
i ich działań ${ }^{6}$. Ten sens oznaczenia chronologicznego z początku perykopy jest potwierdzony zarówno przez odniesienia do miejsca rozmowy prowadzonej podczas zejścia z góry przemienienia, jak i przez sposób przedstawienia adresatów wydarzenia na górze i uczestników tej rozmowy.

\subsection{Znaczenie ram topograficznych}

Przemienienie i wydarzenia $\mathrm{z}$ nim związane mają miejsce na górze znajdującej się na drodze Jezusa do Jerozolimy $(8,27-10,52)$. Droga ta stanowi teologiczną przestrzeń prowadzącą do najważniejszych wydarzeń związanych z misją Jezusa: Jego męki, śmierci i zmartwychwstania. Topograficzne ramy są bardziej wyróżnione niż w przypadku innych oznaczeń miejsca wydarzeń $\mathrm{z}$ różnych okresów Jego działalności. Jeśli ewangelista uwydatnia tę działalność w związku ze zmianami współrzędnych topograficznych, to ogranicza się do przedstawienia Jego przemieszczania się do tych miejsc albo $\mathrm{z}$ nich, ale nigdy nie relacjonuje tego, co dzieje się podczas Jego udawania się do jakiegoś miejsca i opuszczaniu przez Niego tej samej przestrzeni. W tym przypadku jest wyróżnione zarówno Jego udanie się z wybranymi uczniami na wysoką górę, jak i ich wspólne zejście z niej. Na początku dzięki czasowi teraźniejszemu historycznemu czasow-

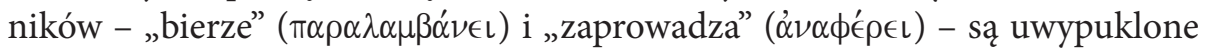
obydwa działania odnoszące się do wejścia na górę na tle następnych wydarzeń

6 Podobna koncepcja upływu czasu wyznaczonego przez Boga znajduje się w Księdze Judyty. Naczelnik miasta ustępuje mieszkańcom Betulii, domagającym się kapitulacji w obliczu śmiertelnego zagrożenia, i wyznacza okres pięciu dni oczekiwania na interwencję Boga, po których upływie miasto ma być wydane Asyryjczykom. Judyta występuje zdecydowanie przeciwko próbie determinowania przez ludzi planów Bożych: „Kim wy właściwie jesteście, żeście wystawiali na próbę w dniu dzisiejszym Boga i postawili siebie ponad Boga między synami ludzkimi? [...] Nie zbadacie głębokości serca ludzkiego ani nie przenikniecie myśli jego rozumu; jak więc wybadacie Boga, który wszystko to stworzył, jak poznacie Jego myśli i pojmiecie Jego zamiary? [...] Gdyby nawet nie zechciał nam pomóc w tych pięciu dniach, to ma On moc obronić nas w tych dniach, w których zechce, albo zgubić nas na oczach naszych wrogów" (Jdt 8,11-15). Zbawienie nie realizuje się według propozycji i planów ludzi, ale w bezgranicznym i bezwarunkowym poddaniu się Bogu. Postawa ta wyraża się w posłuszeństwie mieszkańców wobec Judyty, która schodzi z góry, aby poza murami oblężonego miasta urzeczywistnić Boże ocalenie (Jdt 8,11.17.32-34; 10,10-11); por. A. Malina, Mistagogiczny i pedagogiczny charakter przemienienia, s. 171-173.

7 Ta forma występuje rzadko na początku narracji. Zazwyczaj ewangelista stosuje ją dla podkreślenia wagi jednej czynności na tle innych, już wcześniej przedstawionych, zazwyczaj w aoryście. Na początku perykopy taki emfatyczny czas historyczny posiada wzmianka o wyprowadzeniu Jezusa przez Ducha Świętego na pustynię $(1,12)$ oraz o Jego wstąpieniu na górę i wezwaniu tych, których On chciał $(3,13)$. Między tymi tak zaakcento- 
i czynności, które występują w aoryście, czyli w formie nieokreślonego czasu przeszłego ${ }^{8}$. Nie mniej jest rozszerzone odniesienie do zmiany miejsca w części zamykającej opowiadanie. Podczas schodzenia z góry Marek przytacza nałożony przez Jezusa na uczniów nakaz milczenia i ich reakcję oraz przedstawia ich pytanie zaadresowane do Niego oraz Jego odpowiedź. Takie uwydatnienie ram topograficznych jest ściśle powiązane z podkreśleniem roli trzech uczniów.

\subsection{Wyróżnienie uczniów}

$\mathrm{Na}$ drodze, od samego jej początku, wśród adresatów działalności Jezusa uprzywilejowaną pozycję zajmują uczniowie, którzy są adresatami pierwszej zapowiedzi losu Syna Człowieczego oraz wydarzeń na górze przemienienia. Pierwsze dwa czyny Jezusa dotyczą Jego uczniów: „Jezus bierze Piotra, Jakuba i Jana i zaprowadza ich na górę wysoką samych osobno" $(9,2)$. Zabranie trzech uczniów przypomina pewien szczegół poprzedzający wskrzeszenie córki Jaira. Ze wszystkich towarzyszących osób Jezus zabiera z sobą tych samych trzech uczniów i wchodzi z nimi do domu przełożonego synagogi, nie pozwala zaś wejść innym $(5,37)$. Natomiast zabranie trzech uczniów na górę przemienienia jest opisane wyłącznie pozytywnie - bez wzmianki o powstrzymaniu innych osób. Czas teraźniejszy historyczny służy położeniu emfazy na wybranie nazwanych uczniów i wyprowadzenie ich na wysoką górę. Powtórzenie dopełnienia bliższego po obydwu czasownikach - po pierwszym są wymienione ich

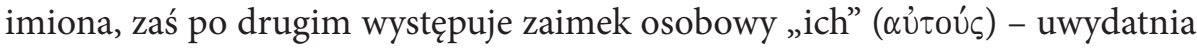
ich rolę jako adresatów tych dwóch czynności. Podobnie przed ustanowieniem Dwunastu, które również ma miejsce na górze $(3,13)$, dwa pierwsze działania Jezusa są zaakcentowane przez użycie czasu teraźniejszego historycznego: „wstępuje” ( $\alpha \nu \alpha \beta \alpha i ́ v \in \iota)$ i „przywołuje” ( $\pi \rho \circ \sigma \kappa \alpha \lambda \in i \tau \alpha \iota)$. Konstrukcja zdania, które otwiera opowiadanie o ustanowieniu Dwunastu, nie przedstawia na pierwszym planie adresatów tych dwóch aktów. Po pierwszym orzeczeniu, który jest czasownikiem nieprzechodnim odnoszącym się do ruchu podmiotu, wskazany

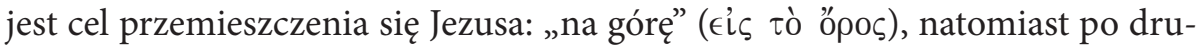

wanymi przemieszczeniami można dostrzec jeszcze jeden paralelizm. Ich cele - pustynia i góra - uważane były od dawna za miejsca zarówno odosobnienia od ludzi, jak i bliskości do Boga. Te przestrzenie oddzielające od innych i umożliwiające zbliżenie się do Boga są scenami innych perykop: Jezus udaje się na miejsce pustynne oraz na górę, aby się modlić $(1,35 ; 6,46$; także przemienienie dokonuje się na górze - 9,2.9).

8 Tryb oznajmujący odróżnia się od konstrukcji u Łukasza, która na pierwszym planie nie ukazuje działań skierowanych do uczniów, ale wejście na górę Jezusa w celu modlitwy: „zabrawszy Piotra, Jakuba i Jana, wstąpił na górę, by się pomodlić” (Łk 9,28). 
gim są wprawdzie wskazane osoby, ale ich tożsamość jest określona względem

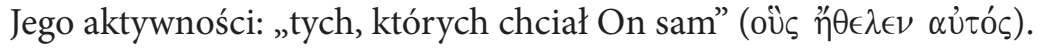

Rola uczniów jest wyróżniona również dzięki przedstawieniu obecności Jezusa w sposób różniący się od całej narracji o Jego publicznej działalności. Uczniowie są więcej niż tylko biernymi świadkami przemienienia, lecz również jego adresatami, a nawet głównymi bohaterami. Jezus natomiast jest prawie cały czas bierny, tak jak był w chrzcie w Jordanie i podczas kuszenia na pustyni (1,9-13), tak jak będzie bierny w męce i śmierci $(14,53-16,6)$. W przemienieniu wszystko dzieje się nie tylko wobec uczniów, ale przede wszystkim dla nich: „tam został przemieniony wobec nich” (9,2); „został ukazany im Eliasz z Mojżeszem, którzy rozmawiali z Jezusem” $(9,4)$; „stał się obłok, osłaniający ich” $(9,7)$; „nagle się rozglądając, nikogo więcej nie ujrzeli, lecz tylko Jezusa samego z nimi” $(9,8)^{9}$. Uczniowie są nie tylko okazyjnymi, przypadkowymi świadkami, lecz także właściwymi protagonistami działania samego Boga, który wprowadza ich w dotychczas niedostępną dla nich tajemnicę osoby i misji Jezusa.

Marek przedstawia reakcję uczniów w sposób odpowiadający ich uprzywilejowanej pozycji. We wprowadzeniu do wypowiedzi Piotra posługuje się czasownikiem w czasie teraźniejszym historycznym: „I odpowiedziawszy Piotr mówi $\left(\lambda \epsilon^{\prime} \gamma \in \iota\right)$ Jezusowi” $(9,5)$, podczas gdy pozostali synoptycy stosują

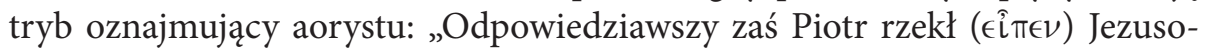

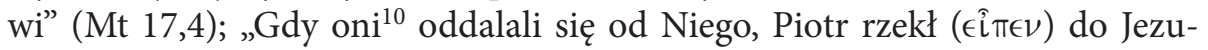
sa (Łk 9,33)”. To zaakcentowanie przez Marka reakcji Piotra jest identyczne w dwóch innych tekstach drugiej Ewangelii: w jego odpowiedzi na pytanie o zdanie uczniów na temat tożsamości Jezusa $(8,29)$; w przypomnieniu przez niego słów skierowanych do drzewa figowego $(11,21)$.

Choć w Biblii gościnność spotyka się z pochwałą ${ }^{11}$, Marek negatywnie ocenia propozycję, by przyjąć Jezusa, Mojżesza i Eliasza przez postawienie im na-

9 W trzeciej Ewangelii zdarzenia są przedstawione bez wskazania ich adresatów: „wygląd Jego twarzy stał się różny, a jego szata biała promieniująca” (Łk 9,29); „oto dwaj mężowie rozmawiali z Nim [...] którzy będąc ukazani w chwale, mówili o Jego odejściu” (Łk 9,30-31).

10 W paraleli Łukaszowej zaimek oznacza Mojżesza i Eliasza.

11 Reakcja Piotra mogła być inspirowana zarówno postawą biblijnych bohaterów wobec Mojżesza i Eliasza (Wj 2,16-22; 1 Krl 17,8-16), jak i centralną pozycją w przemienieniu trzech postaci skojarzonych przez niego z przyjętymi przez Abrahama również trzema osobami (Rdz 18,1-8). Temat gościnności jest zaakcentowany w tej pierwszej narracji przez kontrast z postępowaniem mieszkańców Sodomy (Rdz 19,1-9). Ten podwójny motyw pojawia się w mitach opowiadających o bogach (greckich - Zeusie i Hermesie, rzymskich - Jowiszu i Merkurym), którzy jako przemienieni w anonimowych i ubogich podróżnych zeszli na ziemię, aby znaleźć gościnę u ludzi. Na końcu bezowocnych poszukiwań znaleźli bied- 
miotów. Mateusz nie ma żadnej charakterystyki, natomiast Łukasz podaje ją jakby tylko na marginesie - w zwrocie imiesłowowym: „nie wiedząc, co mówi” (Łk 9,33). Marek rozwija ją w dwóch zdaniach wyjaśniających: „Nie wiedział bowiem, co ma odpowiedzieć, byli bowiem przelękli” $(9,6)$. Na czym polega jego ignorancja, pokazują zarzuty Jezusa kierowane do wszystkich uczniów, które nie są tak mocno zaakcentowane przez pozostałych synoptyków $\left(4,13^{12}\right.$; $\left.7,18^{13} ; 8,17-21^{14}\right)$.

Marek uwydatnia rolę uczniów jako adresatów głosu z nieba. We wszystkich trzech wersjach polecenie słuchania jest sformułowane w 2 . osobie liczby mnogiej: „słuchajcie Go” (Mt 17,5; Mk 9,7); „Go słuchajcie” (Łk 9,35). W narracji Marka uczniowie od początku są adresatami całej teofanii. Obłok, z którego rozbrzmiewa głos, pojawia się jako „zacieniający im” przedmiot wizji, czyli zasłaniający uczniom. Pojawienie się obłoku i głosu jest zatem odpowiedzią, która koryguje reakcję Piotra, wyróżnioną przez użycie czasu teraźniejszego: "odpowiedziawszy Piotr mówi”. Tej funkcji nie posiada teofania w pozostałych synoptykach, gdyż rozpoczyna się ona już w trakcie jego wypowiedzi ${ }^{15}$ : „Gdy

nych małżonków, którzy jako jedyni wśród ludzi przyjęli ich ochoczo. Bogowie hojnie nagrodzili gościnną parę, natomiast zgładzili innych mieszkańców okolicznej krainy. Świadkiem tej ludowej tradycji o gościnności jest rzymski poeta Owidiusz (Metamorfozy VIII, 618). Jej echo znajdujemy także w drugiej księdze Łukasza (Dz 14,8-18). Kiedy z powodu cudu dokonanego przez Pawła i Barnabę mieszkańcy Azji Mniejszej wzięli ich za Hermesa i Zeusa, natychmiast pragnęli oddać im boską cześć. To przyjęcie kontrastowało z oporem żydowskich mieszkańców, którzy okazali się niegodnymi życia wiecznego (Dz 13,45-46).

12 W paralelnych tekstach dwóch pozostałych synoptyków (Mt 13,18; Łk 8,11) nie ma krytyki ich niewiedzy, którą wyrażają retoryczne pytania Jezusa: „Nie znacie tej przypowieści? A jak wszystkie przypowieści poznacie?”.

13 W pierwszej Ewangelii krytyka uczniów jest osłabiona nie przez rzekomą modyfikację samego zarzutu, którą dostrzega A. Paciorek (tenże, Ewangelia według świętego Mateusza, s. 69), lecz przez to, że ona następuje zaraz po o wiele mocniejszym i rozbudowanym oskarżeniu faryzeuszów (Mt 15,13-14), których Jezus nazywa „ślepymi przewodnikami ślepych" (Mt 15,14). Innymi słowy, w Ewangelii Marka zarzut pod adresem uczniów brzmi mocniej bez tej grzmiącej wypowiedzi o Jego przeciwnikach. Łukasz nie ma paraleli do tej perykopy.

14 Podczas gdy perykopa Marka kończy się pytaniem retorycznym Jezusa, które jest apelem o rozumienie znaczenia Jego działalności, paralela Mateusza zamyka się stwierdzeniem o zrozumieniu przez uczniów Jego wypowiedzi jako ostrzeżenia przed nauką faryzeuszów i saduceuszów (Mt 16,12). W trzeciej Ewangelii brak tekstu paralelnego do tej perykopy.

15 W tej Ewangelii nie ma więc fazy, której funkcja jest wprawdzie trafnie określona przez K. Bergera: „Pomiędzy wizją a słyszeniem znajduje się - równie klasycznie i typowo krótka faza, w której wyraźne staje się, że uczniowie nie zrozumieli tego, co zostało objawione w wizji i że tym samym konieczne jest kolejne oświecenie w 17,5-9" (tenże, Ewangelia 
jeszcze on mówił” (Mt 17,5); „Gdy on zaś to mówił” (Łk 9,34). Z tego powodu Mateusz i Łukasz skupiają uwagę na przedmiocie teofanii: „obłok zacienił ich”, czyli Jezusa, Mojżesza i Eliasza, a nie uczniów.

Bardzo ograniczona wzmianka o reakcji uczniów na pojawienie się obłoku i głosu z nieba w drugiej Ewangelii może sugerować, że Marek nie jest koherentny w akcentowaniu roli uczniów. Ewangelista ten wskazuje tylko na natychmiastowość ich percepcji po głosie z nieba: „nagle się rozglądając, nikogo więcej nie ujrzeli, lecz tylko Jezusa samego z nimi” (Mk 9,8). Natomiast w tekstach paralelnych ich reakcja jest ukazana bardziej szczegółowo. Mateusz przedstawia trzy rodzaje powiązanych ze sobą działań. Najpierw ukazuje reakcję uczniów na głos z nieba: „usłyszawszy uczniowie padli na twarze i przelękli się bardzo" (Mt 17,6). Następnie zwraca uwagę na ponowne przejęcie inicjatywy przez Jezusa, który reaguje na te dwa ich akty: „podszedł [...] dotknąwszy ich rzekł: «Podnieście się i nie lękajcie się»" (Mt 17,7). Na końcu opowiada o wykonaniu pierwszego polecenia: „Podniósłszy zaś oczy swoje, nikogo nie ujrzeli oprócz samego Jezusa" (Mk 17,8). Łukasz zaś po wzmiance o znalezieniu się samego Jezusa informuje o milczeniu uczniów, zamykając w ten sposób narrację bez sceny zejścia z góry, która byłaby paralelna do innych synoptyków (Mt 17,9-13; Mk 9,9-13), gdyż obecny w nich zakaz mówienia byłby zbędny wobec tej wzmianki o milczeniu. Mniej rozbudowany Markowy opis reakcji uczniów na teofanię sprawia wrażenie, że fragment relacjonujący rozmowę Jezusa i uczniów podczas zejścia z góry ściślej łączy się z poprzednimi wersetami. W tej Ewangelii wyraźniej widać, że uczestnictwo trzech uczniów w przemienieniu nie kończy się na teofanii zawierającej wezwanie do słuchania Jezusa, ale obejmuje także weryfikację ich gotowości do przyjmowania Jego słowa ${ }^{16}$.

naszego Pana Jezusa Chrystusa, s. 66). Jednak z braku tej fazy u Mateusza komentujący nie wyciąga właściwego wniosku, kiedy pisze o ujawnionym niezrozumieniu uczniów.

16 Brak zmiany miejsca, czasu i osób determinują przynależność 9,11-13 do 9,2-10; por. E. Manicardi, Il cammino di Gesù nel Vangelo di Marco, s. 101: „La discesa dal monte (v. 9a) serve probabilmente a esplicitare, a livello dello sfondo narrativo, la relazione tra l'episodio della trasfigurazione e i contenuti del dialogo ai vv. 9-13"; także C. Breytenbach, Nachfolge und Zukunftserwartung nach Markus, s. 251: „Das Verbot Jesu in Mk 9,9 und das darauffolgende Unverständnis der Jünger helfen dabei, einen linearen kohärenten Übergang zwischen der Verklärungserzählung und dem Gespräch herzustellen”. Pytanie o Eliasza przywołuje ponadto jego pojawienie się w przemienieniu. Niewątpliwie kolejne sceny (9,2-8.9-10.11-13) tworzą jedną narrację, w której znaczenie poszczególnych części odsłania się w jej całości. 


\section{Zakaz opowiadania i jego przyczyny}

Przed wskazaniem przyczyny zakazu Jezusa należy dokładnie określić sposób jego wprowadzenia i treść. Znaczenie tych elementów pomaga odsłonić powody, dla których nie pozwolił On naocznym świadkom przemienienia na opowiadanie o ich doświadczeniu. Ograniczenie czasowe zakazu - aż do zmartwychwstania Syna Człowieczego - również jest powiązane z przyczynami zakazu.

\subsection{Charakterystyka polecenia}

Treść zakazu mówienia jest wprowadzona przez zdanie ze znaczącym w Ewan-

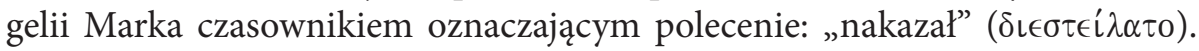
$\mathrm{W}$ tej Ewangelii, poza $\pi \rho 0 \sigma \tau \alpha \dot{\sigma} \sigma \sigma \epsilon \nu$ (hapax legomenon w 1,44), występują trzy kategorie czasowników, które znajdują się we wprowadzeniach narracyjnych do nakazów Jezusa:

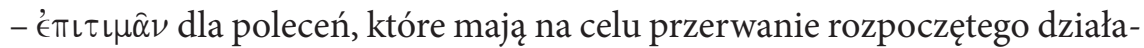
nia $(1,25 ; 3,12 ; 4,39 ; 8,30.32 .33 ; 9,25 ; 10,13.48)$;

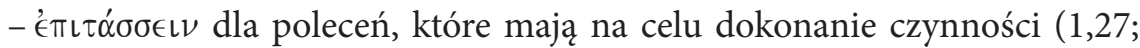
6,27.39; 9,25);

- $\delta\left\llcorner\alpha \sigma \tau \tau^{\prime} \lambda \lambda \epsilon \sigma \theta \alpha \iota\right.$ dla poleceń, które mają na celu przeszkodzenie potencjalnemu działaniu $\left(5,43 ; 7,36\right.$ [dwa razy]; 8,15; 9,9 ${ }^{17}$.

W pierwszej wzmiance użytego tutaj czasownika pojawia się nakaz milczenia, skierowany do świadków wskrzeszenia córki Jaira. Jego zachowanie ma ma celu utwierdzenie żałobników w przeświadczeniu o tym, że dziecko spało, a nie umarło $(5,43)$. Kiedy Jezus bowiem wchodził do miejsca, gdzie znajdowała się dziewczynka uznana przez obecnych za zmarłą, to mówił im o jej śnie, aby ich przekonać, że nie ma intencji zaciągnięcia nieczystości $(5,39)$. W następnej, podwójnej wzmiance tego rodzaju polecenia cudotwórca przez analogiczny zakaz mówienia pragnie nie dopuścić do przeszkodzenia Jego działalności przez rozpowiadających o Jego cudach $(7,36)$. Podobnie jak w przypadku oczyszczenia trędowatego ta próba powstrzymania ich przed opowiadaniem o cudach okazuje się nieskuteczna, gdyż musi On przebywać na miejscach pustynnych, tak że ludzie z daleka przybywają do Niego $(1,45 ; 8,4)$. W trzecim przypadku Jezus przestrzega uczniów przed grożącym im negatywnym wpływem ze strony faryzeuszów i zwolenników Heroda, którzy nie przyjmowali Jego cudów jako objawiających prawdę o Jego tożsamości, kiedy przez żądanie znaku z nieba

17 Rozróżnienie zaproponowane po raz pierwszy w A. Malina, Gli scribi nel Vangelo di Marco, s. 141-142. 
chcieli zweryfikować Jego wiarygodność jako proroka podobnego do Eliasza $(8,15)^{18}$. W tych wszystkich sytuacjach nakazujący chce powstrzymać adresatów poleceń przed przyjęciem postawy szkodliwej dla dalszej Jego publicznej działalności. Negatywny wpływ tej postawy wynika z braku właściwego rozumienia przez ludzi znaczenia osoby zamierzającej dalej działać. Czy w przypadku uczniów schodzących z góry brak występuje po ich stronie czy może wynika tylko $\mathrm{z}$ natury przedmiotu?

Choć Mateusz przytacza polecenie skierowane do uczniów, to jednak jego treść odnosi się do przedmiotu ich widzenia, a nie do ich aktywności: „nikomu

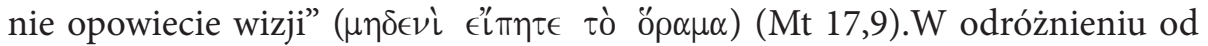
niego nakaz u Marka dotyczy milczenia o treści percepcji uczniów na górze:

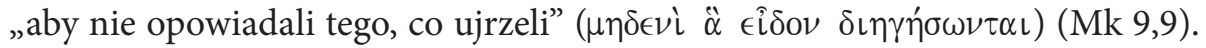
Jego przedmiotem nie jest to, co zostało im obiektywnie ukazane, lecz to, co było przez nich widziane. W Ewangelii Marka wszyscy adresaci działalności Jezusa, którzy są podmiotami czasownika „widzieć” (ópâv), są przedstawieni negatywnie jako uczestniczący w tego rodzaju niedoskonałym poznaniu. Duchy nieczyste wprawdzie dokładnie rozpoznają znaczenie tego, co widzą, to jednak ich działania wynikające z tego poznania pozostają nieskuteczne, co pokazują ich próby przeszkodzenia egzorcyzmom $(1,24.34 ; 3,12 ; 5,7)$. Ludzie natomiast nie rozpoznają właściwie, nie działają odpowiednio albo ich działania lub sądy domagają się pewnej korekty bądź uzupełnienia $(2,12.16 ; 5,14-16.22$; $6,33.49-50 ; 7,2 ; 8,24 ; 9,15.38 ; 12,28 ; 14,67.69 ; 15,32.36 .39 ; 16,5)$. Tylko widzenie Jezusa jest wolne od jakiegokolwiek błędu i niedokładności, a Jego słowa i działania, które wynikają z takiego poznania, osiągają zawsze zamierzony cel. Ten typ poznania jest obecny w: widzeniu działania Bożego po przyjęciu przez Niego chrztu od Jana $(1,10)$; powołaniu Jego uczniów $(1,16.19 ; 2,14)$; słowach korekty i odpowiednim działaniu skierowanym do osób widzianych przez Niego $(2,5.8 ; 6,34.48 ; 8,33 ; 9,25)$; sądach o relacji tych osób do królestwa Bożego $(10,14 ; 12,34)$; patrzeniu odmiennym od spojrzenia towarzyszących Mu ludzi $(5,32 ; 9,14 ; 11,13.20)$.

W poprzednim wersecie wzmianka czasownika „widzieć” odnosi się do percepcji uczniów na górze, która przedstawiona jest jako ostatni akt ich reakcji

18 W ich żądaniu przydawka przyimkowa „z nieba” przypomina o cudach dokonywanych przez Eliasza (1 Krl 18,38; 2 Krl 1,10.12.14). Część ludzi utożsamia nauczającego cudotwórcę z największym prorokiem działającym w królestwie Izraela (Mk 6,15). Za tą identyfikacją przemawiały analogie, które nasuwały się między działalnością Jezusa a cudami Eliasza i Elizeusza. Od tych postaci pochodzą bezwarunkowe wezwania do powrotu do Boga, ich działalność ma wędrowny charakter, a zwłaszcza niektóre cuda upodabniają Jezusa do tych dwóch proroków: rozmnożenie pokarmu (1 Krl 17,8-16; 2 Krl 4,42-44) i wskrzeszenie zmarłej osoby (1 Krl 17,17-24; $2 \mathrm{Krl} 4,18-37)$. 
na przemienienie, które wymaga nieustannej korekty: „nagle się rozglądając, nikogo więcej nie ujrzeli, lecz tylko Jezusa samego z nimi ${ }^{19 ”}(9,8)$. W ten sposób Marek przypomina o ich powołaniu do więzi z Nim $(3,14)$ - jest to temat mocno zaakcentowany w całej jego Ewangelii. W przemienieniu bowiem nie chodzi o zewnętrzne, czysto materialne przyjęcie wszystkich trzech postaci, które ukazały się uczniom. Mojżesz i Eliasz są podporządkowani Jezusowi. Na górze przemienienia nie ma miejsca rozmowa trzech równorzędnych partnerów, lecz najwięksi prorocy zwracają się w rozmowie do Jezusa, tak jak oni sami rozmawiali z Bogiem na Synaju-Horebie (Wj 34,34-35; 1 Krl 19,9-18). Również uczniowie mają zwrócić się całkowicie do Jezusa.

Treść polecenia Jezusa jest przedstawiona w mowie zależnej: „aby nie opowiadali, co ujrzeli". Sens zakazu opowiadania nie tylko wynika $\mathrm{z}$ ich nierozumienia treści i celu przemienienia, ale także jest podporządkowany zadaniu, do którego zostali powołani. Uczniowie nie są wezwani do opowiadania o własnych doświadczeniach i wrażeniach, lecz głoszenia osoby i słowa Jezusa. Obydwa terminy - "głosić” i „opowiadać” - nie są równoznaczne, chociaż występują blisko siebie w Ewangelii Marka. Czasownik „opowiadać” ( $\sigma \theta \alpha \iota)$ ma zdecydowanie negatywną konotację ${ }^{20} \mathrm{~W}$ opisie egzorcyzmu dokonanego w ziemi Gerazeńczyków, kiedy odnosi się do reakcji naocznych świadków wyrzucenia złego ducha - Legionu: „I opowiedzieli im ci, którzy widzieli, jak stało się opętanemu oraz o świniach" $(5,16)$. Bezpośrednim następstwem opowiadania naocznych świadków egzorcyzmu jest sprzeciw wobec działalności Jezusa w tym regionie: „I zaczęli Go błagać, aby odszedł od ich granic” $(5,17)$.

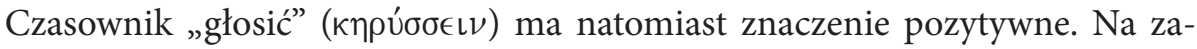
kończenie tego samego opowiadania narrator przedstawia korzystnie działalność uzdrowionego, wzmiankując pozytywną reakcję adresatów tego kerygma-

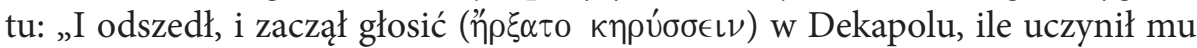
Jezus. A wszyscy się dziwili” $(5,20)$. Zadaniem uczniów nie jest opowiadanie o Jezusie, zdawanie relacji z tego, co jest dostępne ich zmysłom. Świadkowie przemienienia należą do Dwunastu ustanowionych przez Jezusa w celu spełniania trzech zadań: „I uczynił Dwunastu, których nazwał również Aposto-

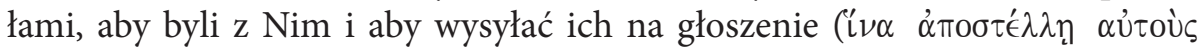

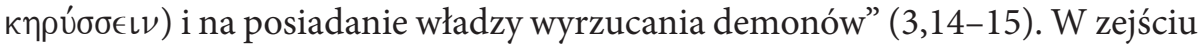
$\mathrm{z}$ góry przemienienia ujawnia się ich trudność $\mathrm{w}$ realizacji drugiego $\mathrm{z}$ trzech zadań, do których zostali ustanowieni jako apostołowie: „aby głosić”. Na związek z potrójnym celem ustanowienia Dwunastu wskazuje dalszy ciąg narracji

19 To wyrażenie przyimkowe występuje tylko w Markowym opisie percepcji uczniów na zakończenie teofanii.

20 Nie ma tego znaczenia w trzeciej Ewangelii (Łk 8,39; 9,10). 
po zejściu z góry przemienienia. Zaraz u jej stóp objawia się kryzys w realizacji trzeciego zadania: pozostałych dziewięciu nie umie wyrzucić ducha głuchoniemego $(9,18)$. Natomiast przed przemienieniem, zaraz po pierwszej zapowiedzi losu Syna Człowieczego (8,31), ujawnia się kryzys pojmowania przez Dwunastu zadania bycia z Nim. Piotr bierze Jezusa do siebie $(8,32)$. Gest ten jest próbą zmienienia wyznaczonego przez plan Boga kierunku drogi, powstrzymania Jezusa przed dalszym podążaniem do celu wskazanego w zapowiedzi męki Syna Człowieczego, narzucenia na Jego drogę własnego postępowania.

\subsection{Ograniczenie czasowe zakazu}

Braki uczniów we właściwym rozumieniu przemienienia nie ustają wraz z przyjęciem polecenia Jezusa nieopowiadania o tym, co widzieli. Ich reakcja na zakaz nie wyraża adekwatnej gotowości słuchania, do którego wezwał ich głos z nieba, ponieważ nie rozumieją, co znaczy powstać z martwych, zaś brak wzmianki o ich końcowej reakcji przenosi uwagę na następne perykopy, które ukazują ich trudności w rozumieniu oraz w przyjmowaniu Jego słów i czynów.

Dyskusja uczniów na temat tego, co znaczy „powstać z martwych” $(9,10)$, może wydawać dziwna zarówno w kontekście samej Ewangelii, jak i w kręgach judaizmu czasów Jezusa. Tych samych trzech uczniów Jezus wziął z sobą do domu Jaira, gdzie byli świadkami wskrzeszenia córki przełożonego synagogi (5,40-42). Ich dyskusję wywołuje podwójna trudność rozumienia Jego słów. Najpierw w logice narracji nakaz milczenia, ograniczony do zmartwychwstania, wydaje się stać $\mathrm{w}$ sprzeczności z poprzednim zakazem mówienia, który miał ich również dotyczyć - ale po wskrzeszeniu córki Jaira $(5,43)$. Teraz zaś nakaz milczenia o przemienieniu ma przestać obowiązywać po zmartwychwstaniu Syna Człowieczego. W obydwu przypadkach adresatami nakazu są ci sami uczniowie: Piotr, Jakub i Jan. Ponadto pojawia się drugi, poważniejszy problem, który wynika $\mathrm{z}$ ich rozumienia zmartwychwstania jako wydarzenia ostatecznego, ostatecznego aktu wieńczącego dzień Pana (Dn 12,4.9.13). Po tym dniu nie ma miejsca na żadną działalność ludzi, historia ludzi osiąga swój kres, a więc pojawia się niepokonalna trudność: w jaki sposób, komu i w jakim celu po tak rozumianym zmartwychwstaniu ci trzej uczniowie mieliby zacząć opowiadać o tym, co widzieli na górze przemienienia?

Niezrozumienie uczniów świadczy o negatywnym wpływie, jakiemu się poddają ze strony innych ludzi, a zwłaszcza ze strony uczonych w Piśmie. W czasach Jezusa możliwość działalności po zmartwychwstaniu przyjęta jest przez część ludzi, którzy próbują identyfikować Jezusa jako Jana Chrzciciela, uzasadniając tę opinię: „A mówili: «Jan Chrzczący powstał z martwych i dlatego działają dzieła mocy przez niego»" $(6,14)$. To zdanie odrzuca druga grupa, 
powołując się na pojawienie się Eliasza lub zapowiedzianego proroka: „Inni zaś mówili: «Eliasz jest». Inni zaś mówili: «Prorok - jak jeden z proroków»” $(6,15)$. Oczekiwanie przyjścia Eliasza jako proroka przed nadejściem dnia Pańskiego uzasadniały Boże obietnice (Ml 3,23-24; Syr 48,10; por. także Pwt 18,15).

Uczniowie odwołują się nie wprost do tych opinii, które sami uważają za błędne $(8,28-29)$, ale powołują się na doktrynę uczonych w Piśmie o przyjściu Eliasza przed zmartwychwstaniem ciał $(9,11)$. Ta sama doktryna wykluczała możliwość powstania z martwych Jana Chrzciciela i skłaniała część ludzi do identyfikowania działającego w Galilei z Eliaszem. Jezus nie zaprzecza doktrynie skrybów, ale zapowiada wypełnienie się Pism odnośnie do Syna Człowieczego, tak samo jak wypełniły się one odnośnie do Eliasza (9,11-12). Ewangelista nie informuje, czy uczniowie powiązali wypełnienie się Pisma o Eliaszu z męczeństwem Jana Chrzciciela (tak jak w Mt 17,13), ponieważ ukazuje ich nie u celu formacji, ale dopiero na początku drogi do Jerozolimy ${ }^{21}$.

\section{Rola uczniów wobec przemienienia}

$\mathrm{Na}$ drodze za Jezusem nie ma etapów bez znaczenia. Zejście z góry przemienienia okazuje się nie mniej ważne niż samo wydarzenie, które na niej miało miejsce. Wobec jego niezwykłości mogłoby się wydawać, że uczniowie nie potrzebują żadnego uzupełnienia treści, którą przekazał im głos z obłoku ani nie muszą korygować tego, co widzieli na górze.

Głos z obłoku wzywa do posłuszeństwa umiłowanemu Synowi Boga. Razem z Jezusem schodzą z powrotem na ich drogę, która od powołania w Galilei polega na codziennym podążaniu za Nim, stałym słuchaniu Jego słów oraz nieustannym ich przyjmowaniu ze zrozumieniem. Dyskusja nad znaczeniem tych słów wiąże się z ich przyszłym zadaniem głoszenia usłyszanych słów. Dyskusja ta ujawnia niezdolność natychmiastowej realizacji powierzonej misji. Przypomnienie doktryny uczonych w Piśmie wskazuje na niebezpieczeństwo poddania się wpływowi konkurencyjnej i niepełnej nauki. Zapowiadając po raz pierwszy los Syna Człowieczego, Jezus zaakcentował Bożą konieczność odrzucenia Go przez przywódców ludu oraz Jego męki i śmierci. To nauczanie ma pierwszeństwo przed innymi naukami głoszącymi różnego rodzaju postacie determinizmu. Realizacja powołania w świetle słowa Bożego ma prymat przed rzekomo koniecznymi potrzebami i projektami, uwarunkowanymi odkrywaną

21 Studium negatywnego wpływu uczonych w Piśmie w A. Malina, Gli scribi nel Vangelo di Marco, s. 145-153. 
przez socjologię i psychologię nieuchronnością rozwoju społeczeństw i jednostek.

Uczniowie Jezusa mogą w wolności przyjąć lub odrzucić Boży plan zbawienia. O tej możliwości Jezus poucza uczniów zakłopotanych z powodu doktryny uczonych w Piśmie: „Eliasz już przyszedł i uczynili mu, ile chcieli, jak o nim jest napisane" $(9,13)$. Przed Bogiem nikt nie jest poddany żadnemu determinizmowi - każdy może przyjąć lub odrzucić Jego apel o słuchanie Jego Syna. Od uczniów jednak nieraz jest wymagane milczenie o własnych doświadczeniach, by ciągłym mówieniem o nich nie zagłuszyli ani Jego słów, ani podawanego przez Niego ich wyjaśnienia.

\section{Bibliografia}

Berger K. Ewangelia naszego Pana Jezusa Chrystusa. Medytacje do niedzielnych Ewangelii. Rok A, Kielce 2010.

Breytenbach C., Nachfolge und Zukunftserwartung nach Markus. Eine methodenkritische Studie, Zürich 1984.

Egger W., Metodologia del Nuovo Testamento. Introduzione allo studio scientifico del Nuovo Testamento, Bologna 1989.

Heil J.P., The Transfiguration of Jesus: Narrative Meaning and Function of Mark 9:2-8, Matt 17:1-8 and Luke 9:28-36, Roma 2000.

Malina A., Mistagogiczny i pedagogiczny charakter przemienienia $w$ narracji Marka (9,2-13), w: Mistagogia a duchowość, A. Żądło (red.), Katowice 2004, s. 170-181.

Malina A., Gli scribi nel Vangelo di Marco. Studio del loro ruolo nella sua narrazione e teologia, Katowice 2002.

Manicardi E., Il cammino di Gesù nel Vangelo di Marco. Schema narrativo e tema cristologico, Roma 1981.

Langkammer H., Ewangelia według św. Marka. Wstęp - przekład z oryginału - komentarz, Poznań-Warszawa 1977.

Paciorek A., Ewangelia według świętego Mateusza: rozdziaty 14-28. Wstęp, przekład z oryginału, komentarz. Część II, Częstochowa 2008. 